Vol 1 No 22020 Desember 2020

Jurnal AlphaEuclidEdu

Received: 23/11/2020; Revised: 26/11/2020; Accepted: 03/12/2020

\title{
PENGUATAN KARAKTER SISWA PERBATASAN MELALUI INTERNALISASI KEARIFAN LOKAL DALAM PEMBELAJARAN MATEMATIKA
}

\author{
Yulis Jamiah \\ FKIP Universitas Tanjungpura Pontianak \\ yulis.jamiah@fkip.untan.ac.id
}

\begin{abstract}
This research is a study of developing the design of a mathematics learning model based on local wisdom to strengthen the character of junior high school students. Strengthening children's character by internalizing superior local wisdom values in terms of "intellectual development, Spiritual and emotional development, Physical and kinesthetic development, and Affective and Creativity development", in order to children with character can become children through learning mathematics. This goal is achieved in several stages. The first stage is exploring character values according to real conditions in the field. Its shown by using a qualitative approach is supported by written data although from interviews, documentation, observations, and questionnaires. The second stage is the stage of development, design, and testing in a limited scope. The research method used in this research is a development research method with a product trial component. Data collection techniques through observation and questionnaires. Qualitative and quantitative data analysis techniques are complementary. The value of local wisdom comes from cultural products and work cubes, which function as a medium in the learning process which is full of local wisdom values, which have not been used optimally by junior high school teachers. The implementation of the design of this mathematics learning model can train students 'thinking and reasoning in drawing conclusions, develop student creative activities that involve imagination, intuition, and discovery by developing divergent thinking, curiosity, making predictions, and developing students' ability to solve problems and convey information or ideas
\end{abstract}

Keywords: Mathematics Learning Model Design, Local Wisdom Value, Student Character

\section{PENDAHULUAN}

Penguatan karakter siswa melalui harmonisasi olah hati, olah rasa, olah pikir, dan olah raga yang melibatkan kerja sama antara satuan pendidikan, keluarga, dan masyarakat. Kegiatan penguatan karakterr tersebut sebagai bagian dari Gerakan Nasional Revolusi Mental. Proses kegiatannya merupakan gerakan pendidikan di bawah tanggung jawab satuan pendidikan (Perpres No. 87 Tahun 2017). Lebih lanjut Mendikbud (Muhadjir Effendy) mengamanahkan kepada para guru dan tenaga kependidikan untuk membekali penguatan karakter para siswa dimulai sejak tingkat sekolah dasar (SD) hingga sekolah menengah pertama (SMP). Penguatan karakter itu berguna bagi siswa terutama pada jenjang mereka pada berikutnya, sehingga siswa tersebut merupakan generasi yang tumbuh sebagai penerus bangsa jauh lebih handal, nasionalis dan kuat. Siswa yang memiliki karakter kuat mampu memelihara dan membangun Negara Kesatuan Republik Indonesia (TribunNews.com, 12-02-2018).

Masyarakat perbatasan terutama generasi usia sekolah mempunyai potensi kearifan lokal yang dapat dikembangkan, mempunyai nilai strategis berfungsi memelihara dan membangun di wilayah perbatasan, dapat memperkuat prilaku gotong royang atau rasa kebersamaan bangsa dan dapat membangun kepercayaan jati diri bangsa. Selain itu, masyarakat perbatasan terutama siswa-siswa sekolah SMP sebagai agen sosial yang berfungsi melestarikan nilai-nilai kearifan lokal. Sikap atau prilaku siswa tersebut sebagai modal sosial memupuk rasa kebersamaan sehingga tetap 
Vol 1 No 22020 Desember 2020

Jurnal AlphaEuclidEdu

Received: 23/11/2020; Revised: 26/11/2020; Accepted: 03/12/2020

mencintai dan mempertahankan bangsa dan negaranya.

Keberadaan kearifan lokal masyarakat perbatasan disatu sisi merupakan kekayaaan budaya masyarakat perbatasan, namun disisi lain jika ditelusuri menimbulkan suatu masalah yang menyangkut keaharmonisan hubungan kedua Negara, di antaranya ketika masyarakat perbatasan berada pada posisi sulit harus memilih antara semangat rasa kebersamaan tetap mencintai bangsa sendiri dengan kebutuhan ekonomi. Secara geografis, kedekatan akses masyarakat kedua negara lebih leluasa berinteraksi didukung pula secara historis hubungan sosial kedua lebih bersifat emosional diikat hubungan kekerabatan dan adat istiadat. Prilaku adat istiadat negara tetangga yang dominan muncul dan mudah terserap karena tidak adanya filter yang cukup kuat, serta kurang sesuai dengan budi pekerti luhur bangsa Indonesia ini, akan cepat masuk dan mudah ditiru oleh generasi muda.

Nilai-nilai leluhur bangsa Indonesia yang terkenal dan takkan pernah usang hingga kini, yakni: sopan santun, keramah-tamahan, kejujuran, dan menjunjung tinggi semangat kebersamaan atau"kegotong-royongan" serta sikap saling harga menghargai harkat dan martabat orang lain. Nilai-nilai tersebut merupakan warisan budaya dan karakter bangsa serta sebagai pembentuk peradaban bangsa Indonesia. Peradaban ini perlu terus dilestarikan dan dipelihara keberadaannya dalam kehidupan berbangsa dan bermasyarakat sehari-hari. Namun realitanya, dekadensi moral yang luar biasa telah menyebabkan keterpurukan bangsa Indonesia yang dulu dikenal sebagai bangsa santun dan taat beragama menjadi bangsa yang mengalami krisis nilai-nilai karakter bangsa, yang ditandai dengan semakin maraknya kejahatan dan tindakan-tindakan yang tidak mencerminkan nilai-nilai karakter bangsa.

Kenyataan yang mengarah pada penyimpangan nilai kebersamaan atau menggeser nilai gotong royong yang menjadi pilar utama budaya bangsa Indonesia. Oleh karena itu, perlu ada upaya yang mengarah pada penyadaran kembali terkait dengan rasa kebersamaan. Upaya yang dilakukan tidak terlepas dari lima potensi yang perlu dikembangkan melalui pendidikan, yakni: spriritual, emosional, intlektual, sosial, dan jasmani. Pengembangannya harus berdampak dalam pendidikan, yaitu menjadi masyarakat: 1) terpelajar; 2) terdidik; 3) sejahtera; 4) berbudaya; dan 5) beradab (Arif Rahman, 2015). Harapan dampak pendidikan dapat terwujud dengan baik, memerlukan pembelajaran tidak hanya berorientasi pada transfer of knowledge atau memindahkan pengetahuan saja melainkan juga harus berorientasi pada penguatan karakter siswa. Penguatan karakter siswa mutlak harus dilaksanakan sebagai upaya menghadapi ancaman era global. Salah satu upaya penguatan karakter dapat dilakukan melalui menginternalisasikan nilai-nilai kearifan lokal dalam pembelajaran matematika.

Pembelajaran matematika yang terintegrasi dengan kearifan lokal sangat tepat digunakan sebagai media untuk menguatkan karakter siswa di SMP Negeri 1 Perbatasan Jagoi Babang. Pengaktualisasian nilai-nilai kearifan lokal menggunakan produks budaya dan hasta karya daerah setempat. Pembelajaran matematika yang menempatkan siswa sebagai subyek untuk membangun pengetahuannya dengan memahami kondisi dalam lingkungan sekitarnya dapat membentuk nilai-nilai kemanusiaan pada diri siswa (Yulis, dkk, 2013: 50). Fenomena tersebut, adanya upaya untuk membentengi siswa dari sikap maupun prilaku yang sesuai dengan budaya Indonesia yaitu melalui penginternalisasian nilai-nilai kearifan lokal. Melalui pembentukan kepribadian yang 
Vol 1 No 22020 Desember 2020

Jurnal AlphaEuclidEdu

Received: 23/11/2020; Revised: 26/11/2020; Accepted: 03/12/2020

berpedoman pada nilai-nilai luhur, maka siswa sangat kuat untuk memelihara dan membangun Negara Kesatuan Republik Indonesia (NKRI). Salah satu media yang dapat digunakan untuk memberikan penguatan karakter dalam pembelajaran dengan menginternalisasikan nilai kearifan lokal.

Dari uraian tersebut, yang menjadi permasalahan dalam penelitian ini adalah: "Bagaimana menguatkan karakter melalui internalisasi nilai kearifan lokal dalam pembelajaran matematika di SMP Negeri 1 Jagoi Babang?" Untuk menjawab permasalahan tersebut, dirinci dalam beberapa pertanyaan penelitian: a) nilai kearifan lokal apa saja yang di imternalisasikan dalam pembelajaran matematika?; b) nilai-nilai karakter apa saja yang dikuatkan dalam pembelajaran matematika?; c) bagaimana penguatan karakter siswa melalui internalisasi nilai kearifan lokal?; d) bagaimana desain model pembelajaran matematika yang menguatkan karakter siswa melalui internalisasi nilai kearifan lokal?; e) bagaimana proses menguatkan karakter siswa melalui internalisasi nilai kearifan lokal dalam pembelajaran matematika?; f) bagaimana respon siswa dengan adanya penginternalisasian nilai kearifan lokal dalam pembelajaran matematika?; g) bagaimanakah tingkat keterterapan desain model pembelajaran yang dihasilkan?; dan h) bagaimanakah dampak desain model pembelajaran matematika yang dihasilkan untuk menguatkan karakter siswa melalui internalisasi nilai kearifan lokal.

Proses pembelajaran untuk membentuk prilaku siswa yang baik sangat dipengaruhi oleh kondisi kewibawaan dan kewiyataan yang ada pada diri guru selaku pendidik. Karena kondisi tersebut merupakan pilar pembelajaran. Kewibawaan dapat tercipta, jika guru mampu membangun sentuhan yang tinggi terhadap siswa sehingga terciptanya rasa aman dan nyaman bersama pendidiknya. Untuk mengkondisikannya dalam belajar ini, sangat perlu memperhatikan unsur-unsur kewibawaan, yaitu: 1) pengakuan dan penerimaan; 2) kasih sayang dan kelembutan; 3) penguatan; 4) tindakan tegas yang mendidik; dan 5) pengarahan dan keteladanan. Sementara unsurunsur yang ada pada kewiyataan, yaitu: 1) penguasaan materi pembelajaran; 2) penerapan metode pembelajaran; 3) penggunaan alat bantu pembelajaran; 4) pengembangan lingkungan pembelajaran; dan 5) penyelenggaraan penilaian pembelajaran (Phil Y.K., 2012: 110). Guru yang mencintai profesinya demi kemajuan siswa tidak akan merobohkan pilar pembelajaran. Selain itu, guru yang profesional tentu selalu mencerminkan prilaku yang dapat di tauladani oleh siswa, seperti berbahasa dengan bijak, baik dan benar, dengan bahasa yang indah-indah, serta dengan sopan santun akan menumbuhkan pikiran dan sikap positif, menumbuhkan keakraban dan mempererat persaudaraan, menumbuhkan simpati dan empati, menjauhkan lawan bicara dari rasa tertekan atau terintimidasi (Chairil, 2012: 9).

Pembelajaran matematika mempunyai tujuan, yakni membentuk kemampuan bernalar pada diri siswa yang tercermin melalui kemampuan berpikir kritis, logis, sistimatis dan memiliki sifat obyektif, jujur, disiplin dalam memecahkan suatu permasalahan baik dalam bidang matematika, bidang lain, maupun dalam kehidupan sehari-hari. Pembelajaran matematika dapat diartikan sebagai suatu upaya penataan lingkungan yang memberi nuansa agar program belajar matematika tumbuh dan berkembang secara optimal. Pmbelajaran matematika secara sempit, yaitu proses pembelajaran dalam lingkup persekolahan, sehingga terjadi proses sosialisasi individu siswa dengan lingkungannya, seperti guru, sumber atau fasilitas, dan teman 
Vol 1 No 22020 Desember 2020

Jurnal AlphaEuclidEdu

Received: 23/11/2020; Revised: 26/11/2020; Accepted: 03/12/2020

sesama siswa. Pembelajaran matematika humanis merupakan sebuah upaya yang memberikan dukungan bagi pengembangan kemampuan setiap individu secara holistik melalui perhatian terhadap mental, spiritual, etika, estetika, emosi, fisik dan pertumbuhan sosial, serta pengembangan scientific thinking, critical reasoning, problem solving skills, dan communication skill (Junaedi \& Asikin, 2012:116).

Menurut NCTM (2000:11), terdapat enam prinsip untuk mengatasi belajar matematika sekolah, yakni: 1) ekuitas, keunggulan dalam pendidikan matematika membutuhkan ekuitas, harapan yang tinggi dan dukungan yang kuat bagi semua siswa; 2) kurikulum, kurikulum dimaksudkan lebih dari sekumpulan kegiatan: hal itu harus koheren, terfokus pada matematika yang dianggap penting, dan diartikulasikan secara baik melalui penilaian; 3) pengajaran, pengajaran matematika yang efektif membutuhkan pemahaman terhadap apa yang siswa ketahui dan siswa perlukan untuk belajar dan kemudian tantangan serta dorongan untuk belajar secara baik; 4) belajar, siswa harus belajar matematika dengan pemahaman, secara aktif membangun pengetahuan baru dari pengalaman dan pengetahuan sebelumnya, 5) assessment, assessment atau penilaian harus mendukung pembelajaran matematika yang dianggap penting dan memberikan informasi yang berguna bagi guru dan siswa, 6) teknologi, teknologi sangat penting dalam proses belajar mengajar matematika, hal ini mempengaruhi matematika yang diajarkan dan meningkatkan proses belajar siswa.

Selain prinsip untuk mengatasi belajar matematika, ada yang perlu mendapatkan perhatian juga yaitu pendidikan karakter yang merupakan usaha sadar dan terencana dalam menanamkan nilai-nilai sehingga terinternalisasi dalam diri peserta didik yang mendorong dan terwujud dalam sikap dan perilaku yang baik. Pendidikan karakter bukan sekedar mengajarkan mana yang benar dan mana yang salah, pendidikan karakter juga menanamkan kebiasaan tentang hal yang baik sehingga mereka menjadi paham (domain kognitif) mana yang baik dan tidak, mampu merasakan (domain afektif) nilai yang baik, dan terbiasa melakukannya (domain perilaku). Jadi pendidikan karakter terkait erat dengan "habit" atau kebiasaan yang terus menerus dipraktekan atau dilakukan (Dirjendiknas, 2010:10).

Pembentukan dasar karakter siswa yang kuat melalui dua hal yang mengawalnya, yakni pola asuh orang tua di rumah dan budaya di sekolah dan masyarakat. Budaya sekolah dan masyarakat yang beradab membekali rasa malu untuk melakukan perilaku yang menyimpang dari norma agama pada diri siswa. Penanaman karakter melalui pola asuh dan budaya inilah yang menyebabkan siswa menjadi manusia yang beradab, untuk menjadi manusia yang beradab berarti memiliki kemampuan untuk memelihara dan mengembangkan pemahamannya terhadap nilai yang dianut di masyarakat (Arif Rahman, 2015: 11). Pembentukan dasar karakter siswa tidak dapat dilepaskan dari soal-soal penanaman nilai-nilai (transfer of value). Pembelajaran matematika merupakan kegiatan yang menggunakan fungsi dan nilai matematika sebagai alat untuk mencapai tujuan yang ditetapkan. Dalam melakukan proses pembelajaran matematika, pendidik berupaya meningkatkan atau selalu menumbuhkan sikap siswa yang selalu mengapresiasi nilai yang tersirat dalam matemateka. Pada hakekatnya, matematika itu sarat dengan nilai-nilai, seperti: nilai kejujuran, cermat, ketelitian, konsitensi, ulet, tekun, percaya diri, kerja keras dan tanggungjawab. Melalui pemahaman nilai-nilai tersebut diharapkan siswa dapat tumbuh 
Vol 1 No 22020 Desember 2020

Jurnal AlphaEuclidEdu

Received: 23/11/2020; Revised: 26/11/2020; Accepted: 03/12/2020

kesadaran dan kemauan untuk mempraktekkan segala sesuatu yang dipelajarinya. Dengan pembelajaran matematika, diharapkan siswa dapat mempelajari proses berpikir ilmiah terhadap kerangka konseptual dan struktur matematika dalam kehidupan seharihari.

Nilai-nilai luhur yang terkandung dalam kekayaan-kekayaan budaya lokal berupa tradisi, petatah-petitih dan semboyan hidup. Kearifan lokal dapat berupa pengetahuan lokal, keterampilan lokal, kecerdasan lokal, sumber daya lokal, proses sosial lokal, norma-etika lokal, dan adat-istiadat lokal (Robert Sibarani, 2013). Kearifan lokal merupakan pengetahuan yang dikembangkan oleh para leluhur dalam mensiasati lingkungan hidup sekitar mereka, menjadikan pengetahuan itu sebagai bagian dari budaya dan memperkenalkan serta meneruskan itu dari generasi ke generasi. Kearifan lokal terbentuk sebagai keunggulan budaya masyarakat setempat maupun kondisi geografis dalam arti luas. Kearifan lokal merupakan produk budaya masa lalu yang patut secara terus-menerus dijadikan pegangan hidup. Meskipun bernilai lokal tetapi nilai yang terkandung di dalamnya dianggap sangat universal (Sartini, 2004). Mengapa nilai kearifan lokal untuk basis dalam pembelajaran matematika? Salah satu alasannya, karena kearifan lokal di daerah akan mampu mengantarkan siswa untuk mencintai produk budaya daerahnya. Kecintaan siswa pada daerahnya akan mewujudkan ketahanan daerah. Ketahanan daerah merupakan kemampuan suatu daerah yang ditunjukkan oleh kemampuan warganya untuk menata diri sesuai dengan konsep yang diyakini kebenarannya dengan jiwa yang tangguh, semangat yang tinggi, serta dengan cara memanfaatkan alam secara bijaksana.

\section{METODE PENELITIAN}

Penelitian ini dilaksanakan dalam tiga tahap, yaitu: 1) memaparkan kondisi nyata di lapangan yang berkaitan dengan penguatan nilai karakter melalui internalisasi nilainilai kearifan lokal pada pembelajaran matematika; 2) pengembangan desain model pembelajaran matematika untuk menguatkan nilai karakter melalui internalisasi nilainilai kearifan lokal; dan 3) Validasi, yakni melalui uji coba secara luas dan memfinalkan desain model. Rincian dalam tiap tahap, diuraikan berikut ini.

1) Tahap Pertama

Metode yang digunakan adalah metode penelitian kualitatif. Penelitian ini bertumpu pada suatu fokus masalah. Menurut Moleong (2007: 93) masalah merupakan suatu keadaan yang bersumber dari hubungan antara dua faktor atau lebih yang menghasilkan situasi yang menimbulkan tanda tanya dan dengan sendirinya memerlukan upaya untuk mencari suatu jawaban. Dalam penelitian ini yang menjadi fokus penelitian adalah: 1) nilai-nilai karakter yang ditanamkan dalam pendidikan karakter di SMP Negeri 1 Jagoi Babang; 2) menginternalisasikan nilai-nilai kearifan lokal melalui pembelajaran matematika; dan 3) penguatan nilai karakter melalui kearifan local.

Penelitian dilaksanakan di Jagoi Babang Kabupaten Bengkayang. Dengan subyeknya siswa kelas VII SMP Negeri 1 Jagoi Babang. Penelitian ini lebih bersifat memaparkan kondisi nyata di lapangan yang berkaitan dengan penguatan nilai karakter melalui internalisasi nilai-nilai kearifan lokal dalam pembelajaran matematika. Penelitian dengan pendekatan kualitatif didukung oleh data dari angket maupun data 
Vol 1 No 22020 Desember 2020

Jurnal AlphaEuclidEdu

Received: 23/11/2020; Revised: 26/11/2020; Accepted: 03/12/2020

hasil wawancara. Penelitian ini diharapkan mampu memberikan gambaran mengenai penguatan nilai karakter melalui internalisasi nilai-nilai kearifan lokal dalam pembelajaran matematika.

Penjaringan dan pengumpulan data dilakukan dengan berbagai cara, yaitu: wawancara, dokumentasi, observasi, dan angket. Sedangkan teknik analisis data dilakukan secara terus-menerus sepanjang penelitian berlangsung dari awal sampai akhir, yaitu mulai dari tahap orientasi sampai pada tahap berakhirnya seluruh program tindakan sesuai dengan karakteristik pokok permasalahan dan tujuan penelitian. Analisis data adalah proses mencari dan menyusun secara sistematis data yang diperoleh dari hasil wawancara, catatan lapangan, dan dokumentasi, dengan cara mengorganisasikan data ke dalam katagori, menjabarkan ke dalam unit-unit, melakukan sintesa, menyusun ke dalam pola, memilih mana yang penting dan mana yang akan dipelajari, dan membuat kesimpulan sehingga mudah dipahami oleh peneliti maupun orang lain (Sugiyono, 2008:89)

Milles and Haberman (Sugiyono, 2008:91) mengemukakan bahwa aktivitas dalam analisis data kualitatif dilakukan secara interaktif dan berlangsung secara terus menerus sampai tuntas, sehingga datanya sudah jenuh. Aktivitas dalam analisis data, meliputi: 1) data reduction (reduksi data); 2) display data (pajangan data); dan 3) conclusion drawing/verification (kesimpulan dan verifikasi data).

2) Tahap Kedua

Penelitian tahap kedua ini berupa suatu pengembangan desain model pembelajaran matematika untuk menguatkan nilai karakter melalui internalisasi nilainilai kearifan lokal bagi siswa SMP. Pendekatan penelitian yang digunakan adalah Developmental Research (Borg \& Gall, 1989: 781-802) berupa siklus yang diawali dengan pengembangan desain model pembelajaran secara konseptual dan dilanjutkan dengan tahapan implementasi. Penjaringan dan pengumpulan data dilakukan dengan berbagai cara, baik tes dan non tes melalui: tes verbal (peragaan) siswa, dokumentasi, observasi, dan wawancara. Sedangkan teknik analisis data yang digunakan dilakukan secara kualitatif dan kuantitatif untuk saling melengkapi.

Penelitian ini dilaksanakan dalam tahapan, yaitu: tahap pengembangan, perancangan, dan uji coba dalam lingkup terbatas. Rincian dalam tiap tahap, diuraikan dalam langkah-langkah sebagai berikut:

a) Mengidentifikasi permasalahan di lapangan berdasar hasil penelitian tahap pertama.

b) Mengkaji permasalahan yang ditemukan pada langkah bagian a dan meninjaunya dari aspek perkembangan kognitif siswa dan permanfaatan pembelajaran matematika;

c) Mengembangkan desain model pembelajaran dengan penginternalisasikan nilai-nilai kearifan lokal untuk menguatkan karakter siswa;

d) Memvalidasi desain model pembelajaran dengan penginternalisasian nilainilai kearifan lokal untuk mendapat masukan dari para ahli, pengguna dan yang lainnya;

e) Menerapkan atau uji coba terbatas dalam bentuk penelitian tindakan dengan tindakan nyata pada mata pelajaran matematika. Sebelum uji coba, dilakukan 
Vol 1 No 22020 Desember 2020

Jurnal AlphaEuclidEdu

Received: 23/11/2020; Revised: 26/11/2020; Accepted: 03/12/2020

pelatihan pada guru pelaksana untuk memahami desain model pembelajaran yang telah dihasilkan.

f) Melakukan evaluasi dan perbaikan desain model pembelajaran matematika dengan penginternalisasian nilai-nilai kearifan lokal untuk menguatkan karakter siswa yang didasarkan langkah bagian e,

3) Tahap Ketiga

Tahap ini merupakan tahap validasi berupa eksperimentasi yang lebih luas. Langkah-langkah yang dilakukan di antaranya:

a) Melaksanakan uji coba yang lebih luas dalam bentuk penelitian tindakan kelas dengan tindakan nyata pada beberapa kelas dalam satu sekolah. Sebelum uji coba, dilakukan pelatihan pada guru pelaksana untuk memahami desain model pembelajaran yang telah dihasilkan.

b) Melakukan evaluasi dan perbaikan model pembelajaran matematika dari langkah bagian a dan menyeminarkannya bersama pelaksana (guru SMP) dan para ahli (dosen-dosen) sehingga diperoleh suatu desain model pembelajaran yang sesuai harapan;

c) Mengungkap keefektifan dan kelemahan penerapan desain model pembelajaran matematika yang dihasilkan dan membandingkannya dengan model pembelajaran yang lazim digunakan;

d) Menetapkan desain model pembelajaran matematika yang dihasilkan sebagai model akhir yang dapat disarankan kepada Sekolah SMP Negeri 1 Jagoi Babang. Nilai efektifitas hasil pengembangan penelitian ini berupa produk kreatif yaitu terbentuknya desain model pembelajaran matematika, yakni pembelajaran yang menciptakan suasana belajar efektif dan menyenangkan, mengedepankan nilai kearifan lokal untuk menguatkan karakter siswa, serta mengoptimalkan pengembangan kognitif yaitu kemampuan: pemecahan masalah, berfikir logis, dan berfikir secara kritis.

\section{HASIL PENELITIAN DAN PEMBAHASAN}

\section{a. Hasil Penelitian}

Berdasarkan pertanyaan-pertanyaan yang diajukan dalam masalah penelitian diperoleh hasil penelitian untuk menjawab beberapa pertanyaaan tersebut sebagai berikut:

1) Beberapa nilai-nilai yang diaplikasikan melalui aktivitas dan kebiasaan di sekolah ternyata sudah sesuai dengan yang nilai-nilai dalam pendidikan karakter yang tertuang pada Permendiknas No. 2 Tahun 2010. Namun, nilai-nilai yang sudah ditetapkan oleh pemerintah melalui pusat kurikulum tersebut tidak menjadi satu-satunya acuan nilai yang ditanamkan kepada peserta didik di dalam pendidikan karakter di SMP Negeri 1 Jagoi Babang. Nilai-nilai karakter yang ditanamkan disesuaikan dengan kebutuhan dan konteks di wilayah perbatasanan. Nilai-nilai karakter tersebut ditanamkan melalui serangkaian kegiatan dan sarana prasarana yang dimiliki oleh sekolah. Terdapat delapan nilai-nilai karakter yang sudah diterapkan secara rutin setiap hari selama lima hari belajar dalam seminggu pelaksaanan pembelajaran di sekolah SMP Negeri 1 Jagoi Babang. Penanaman nilai-nilai secara rutin melalui pembiasaan, tentu dengan maksud agar nilai nilai 
Vol 1 No 22020 Desember 2020

Jurnal AlphaEuclidEdu

Received: 23/11/2020; Revised: 26/11/2020; Accepted: 03/12/2020

tersebut terinternalisasi dan terpolarisasi kejiwa atau kesanubari siswa. Nilai-nilai karakter yang diaktualisasikan dan dinternalisasikan dalam pembelajaran matematika sehingga menguatkan karakter siswa adalah nilai-nilai seperti: jujur, disiplin, bertanggung jawab, ulet/pantang menyerah, sabar, dan tabah. Hal ini seperti pandangan Lickona (1991:51), karakter terbentuk melalui proses knowing the good, feeling the good, acting the good. Pandangan ini memberi arti bahwa pembentukan dan pengembangan karakter melalui proses pemahaman nilai-nilai karakter, menghayati atau meyakini nilai-nilai karakter, dan mewujudkan nilai karakter dalam perbuatan/tindakan.

2) Pada hasil survey data dasar diperoleh data yang berkaitan dengan nilai kearifan lokal, yakni nilai dan norma budaya yang berlaku dalam kehidupan masyarakat. Nilai dan norma yang diyakini kebenarannya menjadi acuan perilaku masyarakat setempat. Proses mengakomodasi nilai kearifan lokal meguatkan nilai karakter dalam pembelajaran matematika mencakup proses: a) mengkaji konsep matematika yang akan di ajarkan, misalkan konsep bidang datar (segitiga, segiempat, lingkaran, trapesium, atau kesimetrian); b) mengkaji media yang sesuai untuk mengajarkan konsep bidang datar yang dipilih tersebut, media yang digunakan seperti: Perisai atau Telawang; c) mengkaji nilai-nilai yang terkadung dalam media yang digunakan.

3) Dalam mengeksplorasi nilai kearifan lokal diperoleh data yang berkaitan dengan nilai kearifan lokal yang berlaku dalam kehidupan masyarakat dan nilai tersebut berkaitan dengan materi yang termuat dalam kurikulum SMP, khususnya mata pelajaran matematika. Hasil kajian keterkaitan antara nilai kearifan lokal dan konsep matematika tertuang pada tabel berikut ini.

Tabel 1. Kajian Nilai Kearifan Lokal Dalam Pembelajaran Matematika di SMP

\begin{tabular}{|c|c|c|c|}
\hline No & $\begin{array}{l}\text { Produk } \\
\text { Budaya }\end{array}$ & Nilai Kearifan lokal & $\begin{array}{c}\text { Konsep } \\
\text { Matematika }\end{array}$ \\
\hline 1 & $\begin{array}{l}\text { Perisai } \\
\text { atau } \\
\text { Talawang }\end{array}$ & $\begin{array}{l}\text { Bentuk Perisai melambangkan kekuatan } \\
\text { dan keteguhan seluruh komponen } \\
\text { masyarakat yang siap menghadapi } \\
\text { berbagai bentuk rintangan serta teguh } \\
\text { dalam memperjuangkan kejayaan dan } \\
\text { kemakmuran. Perisai berfungsi sebagai } \\
\text { pelengkap alat pertahanan diri ketika } \\
\text { berperang, dan sebagai pelengkap dalam } \\
\text { tari-tarian. Konon. Ukirannya memiliki } \\
\text { daya magis yang mampu membang-kitkan } \\
\text { semangat hingga menjadikan kuat orang } \\
\text { yang menyandangnya. Telawang sebagai } \\
\text { pelengkap mandau juga dianggap benda } \\
\text { sakti yang bisa memberikan kekuatan } \\
\text { pada pemiliknya. Talawang merupakan } \\
\text { benda budaya yang lahir dari kepercayaan } \\
\text { masyarakat Dayak terhadap kekuatan } \\
\text { magis. Talawang mengandung makna }\end{array}$ & $\begin{array}{l}\text { Pemahaman } \\
\text { konsep } \\
\text { segitiga, } \\
\text { segiempat, } \\
\text { segi enam, } \\
\text { dan } \\
\text { kesimetrian }\end{array}$ \\
\hline
\end{tabular}


Vol 1 No 22020 Desember 2020

Jurnal AlphaEuclidEdu

Received: 23/11/2020; Revised: 26/11/2020; Accepted: 03/12/2020

\begin{tabular}{|c|c|c|}
\hline & $\begin{array}{l}\text { simbolis yakni lambang kekuatan dan } \\
\text { pertahanan. Selain itu mengandung makna } \\
\text { akan kesatria dan kewibawaan, bagi } \\
\text { pemilik talawang yang dipadukan dengan } \\
\text { mandau menunjukkan pemiliknya tersebut } \\
\text { orang yang pemberani dan kuat. }\end{array}$ & \\
\hline $\begin{array}{l}\text { Rumah adat } \\
\text { Pangah }\end{array}$ & $\begin{array}{l}\text { Rumah adat menggambarkan suatu yang } \\
\text { sakral atau suci tempat bersemayamnya } \\
\text { Jubata (Tuhan), dan menyimbolkan } \\
\text { adanya rasa cinta dan penghormatan } \\
\text { terhadap leluhur (nenek moyang). } \\
\text { Bangunan rumah adat mempunyai tiang } \\
\text { berjumlah } 9 \text { tiang yang bermakna smbolik } \\
\text { angka } 9 \text { bahwa pada angka } 9 \text { dianggap } \\
\text { angka tertinggi yang mempunyai nilai } \\
\text { keberuntungan bagi warga desa. Rumah } \\
\text { adat mempunyai fungsi sebagai wadah } \\
\text { mempersatukan warga dalam memuja } \\
\text { kepada roh-roh nenek moyang }\end{array}$ & $\begin{array}{l}\text { Pemahaman } \\
\text { konsep } \\
\text { segitiga, } \\
\text { segiempat, } \\
\text { lingkaran, } \\
\text { deameter, } \\
\text { jari-jari, } \\
\text { keliling } \\
\text { lingkaran,d } \\
\text { an luas } \\
\text { lingkaran } \\
\text { dan } \\
\text { kesimetrian, }\end{array}$ \\
\hline $\begin{array}{l}\text { Rumah } \\
\text { Betang atau } \\
\text { Radankg } \\
\text { atau Boli } \\
\text { Omu }\end{array}$ & $\begin{array}{l}\text { Rumah Betang terdiri dari } 20 \text { sampai } 40 \\
\text { lawang/pintu, dengan satu tangga untuk } \\
\text { turun naik, dapat diutup dan dinaikan } \\
\text { keatas untuk menjaga keamanan. Rumah } \\
\text { panjang dibangun dengan tiang tinggi } \\
\text { untuk menghindari serangan binatang } \\
\text { buas atau musuh. Rumah Betang menjadi } \\
\text { simbol yang kukuh dari kehidupan } \\
\text { komunal bagi masyarakat Dayak tidak } \\
\text { saja sekadar ungkapan legendaris } \\
\text { kehidupan nenek moyang, melainkan juga } \\
\text { suatu pernyataan secara utuh dan konkret } \\
\text { tentang tata pamong desa, organisasi } \\
\text { sosial serta sistem kemasyarakatan, } \\
\text { menjadi titik sentral kehidupan warganya. } \\
\text { Sistem nilai budaya yang dihasilkan dari } \\
\text { proses kehidupan rumah panjang, } \\
\text { menyangkut soal makna dari hidup } \\
\text { manusia; makna dari pekerjaan; karya dan } \\
\text { amal perbuatan; persepsi mengenai waktu; } \\
\text { hubungan manusia dengan alam sekitar; } \\
\text { soal hubungan dengan sesama. Rumah } \\
\text { betang adalah pusat kebudayaan mereka } \\
\text { karena disanalah seluruh kegiatan dan } \\
\text { segala proses kehidupan berjalan dari } \\
\text { waltu ka waltu Meraka mannintai }\end{array}$ & $\begin{array}{l}\text { Pemahaman } \\
\text { konsep } \\
\text { segitiga, } \\
\text { segiempat, } \\
\text { lingkaran, } \\
\text { deameter, } \\
\text { jari-jari, } \\
\text { keliling } \\
\text { segitiga, } \\
\text { keliling } \\
\text { segi empat, } \\
\text { luas } \\
\text { segitiga, } \\
\text { loas segi } \\
\text { empat dan } \\
\text { kesimetrian, }\end{array}$ \\
\hline
\end{tabular}


Vol 1 No 22020 Desember 2020

Jurnal AlphaEuclidEdu

Received: 23/11/2020; Revised: 26/11/2020; Accepted: 03/12/2020

4) Dalam pemantauan pelaksanaan pembelajaran matematika di SMP diperoleh data yang berkaitan dengan permasalahan pembelajaran matematika, seperti kesenjangan antara model pembelajaran dengan penerapannya, atau kurikulum dan model pembelajaran matematika yang sedang digunakan. Pada Kurikulum Tahun 2013 diakomodasi kompetensi secara komprehensif, yaitu pendidikan harus menghasilkan lulusan yang berkompeten pada aspek sikap, aspek pengetahuan, dan aspek keterampilan, sehingga dapat membantu mempersiapkan anak beradaptasi secara kreatif dengan lingkungan masa kini dan masa depan kehidupannya.

5) Berkaitan dengan pertanyaan tentang apakah pembelajaran matematika yang dilaksanakan saat ini telah mencerminkan adanya nilai-nilai karakter, diperoleh informasi bahwa guru pada umumnya beranggapan pembelajaran matematika belum mencerminkan atau memuat nilai-nilai karakter, tetapi pembelajaran matematika diaplikasikan dalam kehidupan sehari-hari. Dalam pembelajaran matematika diajarkan ketelitian, kecermatan, kejujuran, dan keterampilan memecahkan masalah, dan pada Kurikulkum 2013 sudah tercermin nilai-nilai karakter dengan kegiatan diskusi kelompok seperti adanya nilai disiplin. Tidak semua guru dan sekolah saat ini melaksanakan pembelajaran matematika yang mencerminkan adanya nilai karakter, dan masih terlihat guru melaksanakan pembelajaran matematika secara konvensional.

6) Berkaitan dengan pertanyaan tentang apakah pembelajaran matematika yang dilaksanakan saat ini telah memanfaatkan media hasil karya masyarakat atau daerah setempat sebagai sumber belajar, diperoleh informasi bahwa responden pada umumnya menyatakan sampai saat ini masih belum pernah memanfaatkan media hasil karya masyarakat setempat sebagai sumber belajar dalam pembelajaran matematika, dan sebagian kecil responden menyatakan ada salah satu media pembelajaran yang diaplikasikan dalam hasil karya masyarakat misalnya perisai untuk berperang. Namun pertanyaan ini menginspirasi guru untuk memikirkan karya apa di masyarakat yang lebih inovatif bisa menunjang pembelajaran.

7) Dari hasil angket pada guru matematika berkaitan dengan faktor yang mempengaruhi kemauan guru dalam mengajarkan matematika berbasis nilai kearifan lokal di SMP diperoleh informasi antara lain: adanya keinginan siswa untuk mengenal budayanya sendiri, adanya kreativitas guru, keinginan untuk menciptakan proses pembelajaran menjadi lebih menyenangkan, keinginan untuk memotivasi diri dalam pembelajaran, ketersediaan media di daerah setempat yang berbasis kearifan lokal dan nilai karakter.

8) Berdasarkan hasil angket tentang tentang respon guru terhadap proses pembelajaran matematika diperoleh informasi bahwa seluruh responden setuju jika penyajian matematika melalui pembelajaraan yang menyenangkan, dan penggunaan media dari daerah setempat dalam pembelajaran matematika menunjukkan guru ikut melestarikan keberadaan nilai-nilai lokal dari media tersebut. Beberapa saran yang diajukan guru sehubungan dengan pelaksanaan pembelajaran matematika agar tertata lebih baik antara lain: (i) sebaiknya pembelajaran matematika dibuat dengan menarik sehingga dapat menciptakan 
Vol 1 No 22020 Desember 2020

Jurnal AlphaEuclidEdu

Received: 23/11/2020; Revised: 26/11/2020; Accepted: 03/12/2020

keaktifan dan kreativitas siswa, (ii) perlu adanya pembinaan dari pihak yang lebih menguasai dan memahami serta perlu adanya kerja sama, (iii) guru harus mampu menguasai materi dan bisa memanfaatkan media pembelajaran disekitar agar pelajaran tersebut menyenangkan dan tidak membosankan, (iv) guru harus lebih kreatif dan inofatif dalam melaksanakan pembelajaran matematika, (v) guru harus lebih kreatif dalam membuat setting pembelajaran dan menggunakan RPP yang baik sebagai panduan mengajar, dan (vi) guru harus meningkatkan kompetensinya melalui pengembangan kreativitasnya.

9) Dengan tuntutan kewibawaan dan kewiyataan yang ada pada diri guru berdasarkan informasi di atas, maka perlu disusun desain model pembelajaran yang mencirikan dua hal tuntutan tersebut. Desain model pembelajaran matematika dengan menginternalisaikan nilai kearifan lokal sangat diperlukan karena memberikan bekal pengetahuan, ketrampilan dan perilaku kepada peserta didik agar mereka memiliki wawasan yang mantap tentang keadaan lingkungan dan kebutuhan masyarakat sesuai dengan nilai-nilai/aturan yang berlaku di daerahnya dan mendukung pembangunan daerah serta pembangunan nasional. Desain model pembelajaran matematika yang dikembangkan ini sebagai modifikasi dari model pembelajaran kooperatif dengan mengacu kepada paradigma pembelajaran konstruktivisme. Model pembelajaran ini bertujuan untuk mengembangkan daya matematis siswa secara maksimal dan kemampuan berargumentasi dan berkomunikasi logis, serta mengembangkan kreativitas dan kemampuan berfikir tingkat tinggi. Adapun strategi yang dapat digunakan dalam model pembelajaran ini dapat dilakukan dengan langkah berikut:

a) Mendiskusikan materi yang tertuang dalam LKPD sebagai masalah kelompok. Mengorganisasi permasalahan penting dilakukan dengan berdiskusi dan harus diupayakan agar bermakna bagi setiap anggota kelompok. Masalahnya harus kontekstual, yaitu berkaitan dengan situasi kehidupan nyata bagi siswa, diusahakan memberi jawaban tidak dengan tebakan, dan mencari berbagai solusi yang rasional.

b) Melakukan penyelidikan secara cermat dan autentik. Hal ini dapat dimulai dengan proses saintifik, mulai dari pengamatan, pengajuan masalah, penalaran, percobaan, menganalisis, dan mengembangkan hipotesis, serta penyimpulan.

c) Presentasi hasil kerja kelompok. Mempresentasikan dan memperagakan berbagai hasil kerja, dapat berbentuk laporan pemecahan masalah, atau laporan hasil kegiatan.

d) Bekerjasama dalam kelompok. Memotivasi siswa untuk belajar dalam kelompok kerja kolaboratif yang terdiri dari $4-5$ orang siswa dalam memecahkan masalah yang diberikan. Hal ini bermanfaat untuk memberikan motivasi berkelanjutan pada saat terlibat dalam tugas-tugas yang lebih kompleks untuk pengembangan keterampilan sosial.

\section{b. Pembahasan}

Dari hasil pengamatan pada saat pelaksanaan ujicoba di sekolah di daerah Jagoi 
Vol 1 No 22020 Desember 2020

Jurnal AlphaEuclidEdu

Received: 23/11/2020; Revised: 26/11/2020; Accepted: 03/12/2020

Babang, teridentifikasi bahwa pelaksanaan model pembelajaran matematika berbasis nilai kearifan lokal tersebut dapat berjalan sesuai rencana yang tertuang dalam Rancangan Pelaksanaan Pembelajaran Matematika. Beberapa tahapan kegiatan yang masih belum dapat terlaksana secara maksimal di antaranya sebagai berikut:

1) Pada kegiatan pendahuluan ada tahapan yang belum jelas tersampaikan oleh guru, seperti penyampaian tujuan pembelajaran, pemberian motivasi yang berkaitan dengan kegiatan di masyarakat sehari-hari, dan tanya jawab seputar apersepsi yang belum optimal.

2) Pada kegiatan inti (pengembangan) ada tahapan yang tidak terlaksana, seperti pemberian motivasi bahwa siswa punya peluang menjadi orang sukses, tahap presentasi hasil kerja siswa dilakukan dimeja masing-masing kelompok,

3) Pada kegiatan penutup belum tersampaikan tahapan menugaskan siswa untuk mengembangkan kreativitasnya di rumah terkait pemahaman materi yang baru dipelajari.

Pembelajaran matematika secara manusiawi berkenaan dengan proses pembelajaran matematika yang menempatkan siswa sebagai subyek untuk membangun pengetahuannya dengan memahami kondisi-kondisi dalam diri sendiri maupun lingkungan sekitarnya. Model pembelajaran matematika ini akan membentuk nilai-nilai kemanusiaan dalam diri siswa. Dampak bagi para siswa dengan implementasi model pembelajaran dengan menginternalisaikan nilai kearifan lokal sesuai dengan pengembangan kurikulum di antaranya: melatih cara berpikir dan bernalar siswa dalam menarik kesimpulan, mengembangkan aktivitas kreatif siswa yang melibatkan imajinasi, intuisi, dan penemuan dengan mengembangkan pemikiran divergen, orisinil, rasa ingin tahu, dan membuat prediksi; mengembangkan kemampuan siswa dalam memecahkan masalah; dan mengembangkan kemampuan siswa dalam menyampaikan informasi atau gagasan.

Secara umum tahapan pembelajaran tersebut dapat dilaksanakan oleh guru model. Terlaksananya uji coba pembelajaran tersebut karena adanya berbagai faktor pendukung. Struktur pembelajaran yang diterapkan masih menggunakan struktur pembelajaran pada umumnya dengan tahapan kegiatan mulai dari tahap persiapan, tahap pendahuluan, tahap pengembangan, tahap penerapan, dan tahap penutup.

Berdasarkan hasil pengamatan dan diskusi dalam penelitian ini, pembelajaran matematika dengan menginternalisaikan nilai kearifan lokal memungkinkan untuk diterapkan. Hal ini dapat disebabkan karena struktur pembelajaran yang sama dengan pembelajaran pada umumnya, dan guru yang melaksanakan adalah sarjana pendidikan matematika yang juga sudah mengikuti pelatihan pengembangan pembelajaran termasuk pelatihan penerapan Kurikulum 2013. Guru yang bersangkutan juga merespon secara positif terhadap ujicoba penerapan pembelajaran tersebut.

Berkaitan dengan siswa yang terlibat dalam pelaksanaan uji coba desain model pembelajaran dalam penelitian ini, tampak siswa merespon secara positif setiap tahapan pembelajaran, baik berupa kegiatan diskusi, kegiatan tanya jawab antara guru dan siswa dan juga sesama teman, serta tahapan kegiatan lainnya. Aktivitas diskusi kelompok dalam pembelajaran menjadi kegiatan yang cukup 
Vol 1 No 22020 Desember 2020

Jurnal AlphaEuclidEdu

Received: 23/11/2020; Revised: 26/11/2020; Accepted: 03/12/2020

menyenangkan bagi siswa, karena mereka merasa lebih leluasa belajar dengan sesama teman dari pada hanya memperhatikan penjelasan guru.

\section{KESIMPULAN DAN SARAN}

\section{a. Kesimpulan}

Sasaran utama pembelajaran matematika adalah pengembangan kemampuan proses dalam pemecahan masalah. Untuk itu sajian desain model pembelajaran yang memungkinkan adalah diawali dengan menyajikan masalah yang memerlukan jawaban yang bervariasi dalam cara menyelesaikan atau hasil akhir. Beberapa kesimpulan yang dapat dipaparkan dalam penelitian ini adalah sebagai berikut:

1) Nilai-nilai karakter yang diaktualisasikan dan diinternalisasikan dalam pembelajaran matematika yang dapat menguatkan karakter peserta didik adalah nilai-nilai seperti: jujur, disiplin, bertanggung jawab, ulet/pantang menyerah, sabar, dan tabah. Untuk menguatkan karakter peserta didik melalui internalisasi nilai kearifan lokal dengan cara menceritakan satu diantara produk budaya Dayak Bidayuh, seperti cerita upacara/acara Gawia Sowak yang dilaksanakan oleh masyarakat Dayak Bidayuh setiap tanggal 3 Juni setiap tahunnya. Kandungan cerita memuat beberapa nilai karakter yang dikuatkan, seperti nilai religus, nilai toleransi, nilai disiplin, nilai kerja keras, nilai saling menghargai, nilai cinta damai, nilai peduli lingkungan, dan nilai tanggungjawab, serta nilai gotong royong.

2) Perlunya mengeksplorasi berbagai permasalahan pelaksanaan pembelajaran di sekolah khususnya di daerah perbatasan atau pedalaman. Permasalahan pembelajaran tersebut selanjutnya dikaitkan dengan nilai-nilai kearifan lokal yang sesuai dan berlaku di masyarakat, seperti bentuk perisai yang melambangkan kekuatan dan keteguhan komponen masyarakat yang siap menghadapi berbagai rintangan serta teguh dalam memperjuangkan kejayaan dan kemakmuran.

3) Pembelajaran matematika yang dilaksanakan saat ini belum banyak mencerminkan nilai karakter, dan masih ada sebagian guru melaksanakan pembelajaran matematika secara konvensional, karakter yang dimunculkan dalam pembelajaran matematika masih sulit untuk dicerna siswa. Selain itu guru belum pernah atau jarang memanfaatkan media hasil karya masyarakat sebagai sumber belajar dalam pembelajaran matematika.

4) Faktor yang mempengaruhi kemauan guru dalam mengajarkan matematika berbasis nilai kearifan lokal di SMP antara lain adanya keinginan agar siswa mengenal budayanya sendiri, munculnya kreativitas guru yang bersangkutan, keinginan menciptakan proses pembelajaran menjadi lebih menyenangkan, keinginan untuk memotivasi diri dalam pembelajaran, serta ketersediaan media di daerah setempat yang berbasis kearifan lokal dan nilai karakter.

5) Respon guru maupun siswa terhadap pelaksanaan pembelajaran matematika agar tertata lebih baik antara lain menyarankan pembelajaran matematika dibuat menarik sehingga dapat menciptakan keaktifan dan kreativitas siswa, adanya pembinaan dari pihak yang lebih menguasai dan perlunya kerja sama, guru harus mampu menguasai materi dan dapat memanfaatkan media di sekitar agar 
Vol 1 No 22020 Desember 2020

Jurnal AlphaEuclidEdu

Received: 23/11/2020; Revised: 26/11/2020; Accepted: 03/12/2020

pelajaran tidak membosankan, guru lebih kreatif dan inovatif dalam membuat setting pembelajaran dan melaksanakan pembelajaran.

6) Model pembelajaran matematika berbasis nilai kearifan lokal merupakan model yang mengacu pada aspek pembelajaran matematika secara manusiawi yang menempatkan siswa sebagai subyek untuk membangun pengetahuannya dengan memahami kondisi dalam diri sendiri maupun lingkungan sekitarnya, serta dapat membentuk nilai-nilai kemanusiaan pada diri siswa. Kreativitas guru diperlukan untuk memfasilitasi kegiatan belajar siswa dengan mengacu pada paradigma pembelajaran konstruktivisme. Penerapan model pembelajaran ini dapat melatih cara berpikir dan bernalar siswa dalam menarik kesimpulan, mengembangkan aktivitas kreatif siswa yang melibatkan imajinasi, intuisi, dan penemuan dengan mengembangkan pemikiran divergen, rasa ingin tahu, membuat prediksi, serta mengembangkan kemampuan siswa dalam memecahkan masalah dan menyampaikan informasi atau gagasan.

b. Saran

Berdasarkan hasil penelitian yang tersirat pada kesimpulan di atas dapat dikemukakan beberapa saran berikut ini.

1) Para praktisi pendidikan perlu menggali media atau budaya yang berkaitan dengan nilai-nilai kearifan lokal dan nilai karakter di masyarakat, agar dapat menjadi media dan sumber belajar yang dapat mengatasi permasalahan pendidikan di daerah.

2) Penelitian semacam ini dapat dilaksanakan bersinergi dengan pihak-pihak yang berkepentingan di lapangan, khususnya bagi pemegang kebijakan atau pemuka masyarakat di daerah setempat, sehingga kendala nonteknis yang terjadi tidak terlalu berpengaruh pada pelaksanaan penelitian.

3) Bagi dinas terkait perlu memberi rangsangan dan motivasi kepada para guru/pendidik agar berkeinginan untuk mengembangkan model-model pembelajaran yang lebih kreatif dengan memanfaatkan media dan hasil karya daerah setempat, agar proses pembelajaran menjadi lebih menyenangkan bagi siswa. 
Vol 1 No 22020 Desember 2020

Jurnal AlphaEuclidEdu

Received: 23/11/2020; Revised: 26/11/2020; Accepted: 03/12/2020

\section{REFERENSI}

Aif Rachman (2015). Guru Berdasarkan Catatan Ukim Komarudin, Penerbit Erlangga.

Borg, W.R. \& Gall, D. M. (1989). Educational Reasearch: Introduction. New York: Longman.

Chairif E. (2012) Peranan Bahasa Melayu dalam Membangun Karakter Bangsa, Bahan Seminar Nasional di Hotel Aston Pontianak Tgl 5-6 Juni 2012

Junaidi dan M. Asikin. (2012). Pengembangan pembelajaran Matematika Humanistik untuk Meningkatkan Kemahiran Matematis, Unnes Journal of Mafhematicts Educatioan Research. http://journal.unnes.ac.id/sju/index.php/ujmer. [on-line, diakses 10 Mei 2013].

Kemendiknas. (2010). Pembinaan Pendidikan Karakter di Sekolah Menengah Pertama, Jakarta

. (2011). Panduan Pelaksanaan Pendidikan Karakter, Badan Penelitian Dan Pengembangan Pusat Kurikulum Dan Perbukuan, Jakarta.

Lickona, T. (1991). Educating for Character: How Our Schools Can Teach Respect and Responsibility. New York: Simon \& Schuster, inc.

Moleong, Lexy. (2007). Metodologi Penelitian Kualitatif. Bandung: Rosdakarya

National Council of Teachers of Mathematics. (2000). Principles and standards for school mathematics. Reston, VA: NCTM.

Phil Yanuar Kiram. (2012). Profesi Pendidik Seutuhnya dalam Perseptif Penyiapan Manusia Indonesia Generasi 2045. Materi Konvensi Nasional Pendidikan Indonesia (KONASPI) VII 2012 di Yogyakarta Tgl 31 Oktober - 3 November 2012. Penerbit: UNY Press.

Robert Sibarani. (2013). The character building based on local wisdom. http://www.museum.pusaka-nias.org/2013/02/pembentukan-karakterberbasis-kearifan. html [on-line diunduh 29 April 2013 ].

Sartini. (2004). Menggali Kearifan Lokal Nusantara Sebuah Kajian Filsafati, Jurnal Filsafat, UGM, Edisi Bulan Agustus 2004, Jilid 37, Nomor 2

Sugiyono. (2008). Metode Penelitian Kuantitatif Kualitatif dan $R \& D$. Bandung: Albeta.

Yulis J., dkk (2013). Pengembangan Model Pembelajaran Matematika Humanis Sederhana Berbasis Pendidikan Karakter Bagi Mahapeserta didik Pendidikan Matematika FKIP Untan Pontianak. Laporan Penelitian.

\section{Internet:}

Ahmad S. (2010). Konsep Pendidikan Karakter. (http://akhmadsudrajat.wordpress.com., [On-line diunduh 23 Januari 2012]

Materi Perpres No. 87 Tahun 2017 tentang Penguatan Pendidikan Karakter 